\title{
PERFORMANCE OF BREAD WHEAT DIALLEL AMONG SEVEN- PARENTS UNDER WATER STRESS CONDITIONS
}

\author{
Mohamed A. Abd El-Shafi, A.A. Abd El-Mohsen and S.A. El-Ssadi \\ Agronomy Department, Faculty of Agriculture, Cairo University, Egypt
} ABSTRACT

Seven bread wheat genotypes (line 39, line 54, New valley, V92/17, V99/17, Sakha 8 and Sahel 1) were crossed in a half-diallel mating design and were planted to determine their genetic behavior under water stress conditions. Results were recorded on days to heading, plant height, no. of spikes/plant, no. of grains/spike and grain yield/plant. Results for all traits revealed highly significant $(P<0.01)$ differences among genotypes under water stress conditions. General (GCA) and specific (SCA) combining ability were found to be significant or highly significant for all traits, indicating the importance of additive and non-additive gene actions in controlling the performance of these traits in all genotypes. In general, for all studied traits, the magnitude of mean squares due to GCA was higher than that due to SCA, suggesting that additive was more important than non-additive gene effects in the inheritance of these traits. One superior cross (Line 39 x V 92/17) for grain yield and two crosses (New valley x V 92/17 and Line $54 \times$ New valley) for no. of grains/spike under water stress were considered as promising hybrids for improvement purpose. Moreover, they involved good combiner parents which can be used to improve any of these features.

Key Words: Genetic analysis, Wheat, Water stress, Gene action, GCA, SCA.

\section{INTRODUCTION}

Wheat is one of the four main cereals cultivated worldwide (wheat, rice, maize and barley). However, wheat is the world's most important and widely grown cereals crop. Its importance is derived from many properties and uses of its grains, which make it staple food for more than one third of world's population (Poehlman 1987).

As the world population continues to grow, the arable land area per capita will further decease. Therefore, research on the enhancement of wheat productivity is still an important task for wheat breeders. FAO (1988) estimated that almost two-thirds of the increase in crop production needed in the next decades must come from higher yields per unit land area. Hence, deficit irrigation requires more control over the amount and timing of water application than full irrigation practice.

Wheat is affected by drought stress, either in the plant development stages, or through yield development. Furthermore, there is also a difference in the intensity of the stress that plays a role in both cases. For example, water stress during seed development affects the yield more than that experienced in the vegetative stage (Agenbag and De Villiers, 1955).

Water stress is recognized as an important factor that affects wheat growth and yield (Ashraf, 1988 and Ashraf and Naqvi, 1995). However, wheat species and cultivars within species show substantial differences in their response to soil moisture (Rascio et al., 1992 and Iqbal et al., 1999). Moreover, reduction in yield and yield components due to water stress have been reported in both durum and bread wheat (Sinha et al., 1986). Water stress at various stages before anthesis can reduce plant height as indicated by

Fayoum J. Agric. Res. \& Dev., Vol.23, No.1, January, 2009 
El-Banna et al. (2002). Substantial losses in grain yield caused by water deficiency depending on the developmental stage at which water stress occurs (Ozturk and Aydin 2004).

Yield losses due to certain stresses may be minimized in early-maturing cultivars, since they would escape such stress that might occur late in season (Clarke et al. 1984 and Menshawy 2005). However, some investigators reported that early-maturing cultivars were more drought tolerant than late ones (Fischer and Maurer 1978 and Kheiralla et al. 1993). Additive gene action is evidently accounted for a large amount of the variation for days to heading (Bhatt 1972, Avey et al. 1982, and Menshawy 2000and 2005), but dominance was also important for earliness traits (Crumpacker and Allard 1962, Avey et al. 1982 and Menshawy 2005).

Understanding the genetic behavior of yield attributes under water stress is very important for any breeding program because the progress was less under water-limiting environments in many regions (Richards et al. 2001). In addition, Selection for high grain yield and improved performance under drought is not always successful (Cooper et al. 1997). Therefore, genetic improvement of grain yield under water stress limitation is still a key objective for wheat breeders (Richards et al. 2002).

On the other hand, yield has low heritability, slow and difficult to be measured especially in early segregation of a breeding program (Rebetzke $\boldsymbol{e t}$ al. 2002). Meanwhile, Arshad and Chowdhry (2003) reported over dominance and additive gene action for grains/spike under drought conditions. In certain cases, over dominance has also been reported by Kashif and Khaliq (2003) for plant height and grain yield per plant under normal irrigation conditions.

Several researchers have concluded that selection will be most effective when the experiments are done under both favorable and stress conditions (Fischer and Maurer, 1978, Clarke et al., 1992 and Nasir Ud-Din et al., 1992).

This study was undertaken to determine the nature of genetic mechanisms of some traits in wheat crosses exposed to water stress and to identify superior genotypes, which have good performance for earliness, plant height as well as grain yield and its components under water stress.

\section{MATERIALS AND METHODS}

The experimental field work of this investigation was carried out at Agricultural Experiments and Research Station, Faculty of Agriculture, Cairo University, during 2006/2007 and 2007/2008 seasons. All possible crosses (excluding reciprocals) were made among seven bread wheat parental genotypes in a half diallel cross mating design during 2006/2007 seasons. So, seeds of $21 \mathrm{~F}_{1}$ crosses were obtained. In the second seasons (2007/2008) an experiment was conducted for evaluating the $21 \mathrm{~F}_{1}$ crosses and their 7 parents under water stress conditions. The pedigree and origin of the studied genotypes are listed in Table (1). The materials were planted in a Randomized Complete Block Design with three replications. Each replicate consisted of 28 rows , $3 \mathrm{~m}$ long and $30 \mathrm{~cm}$ apart with $20 \mathrm{~cm}$ between plants. Water stress plots received water only at planting. Sowing was done in the third week of November. Five guarded plants were randomly chosen from each row to measure; days to heading, plant height, no. of spikes/plant, no. of grains/spike, and grain yield/plant.

The collected data were checked out for normality distributions in each trait by the Wilk Shapiro test (Neter et al., 1996). Data were statistically

Fayoum J. Agric. Res. \& Dev., Vol.23, No.1, January, 2009 
analyzed using ANOVA and LSD value was employed for the mean comparisons in the MSTAT-C software package (Freed $\boldsymbol{e t}$ al., 1989). Genotypes degrees of freedom were partitioned into parents, crosses and parent $v s$. crosses.

General (GCA) and specific (SCA) combining ability variances and their effects were estimated according to Griffing`s method I model II (Griffing 1956).

Table (1): Names, pedigree and origin of the studied parental genotypes.

\begin{tabular}{|c|c|c|c|}
\hline No. & Genotypes & Pedigree & Origin* \\
\hline 1 & Line 39 $\left(\mathrm{P}_{1}\right)$ & TEVEVEEE"S"/SHUHA"S" & Egypt \\
2 & Line 54 $\left(\mathrm{P}_{2}\right)$ & KUZ*2/MNV//KAUZ & Egypt \\
3 & New Valley $\left(\mathrm{P}_{3}\right)$ & Not available & Egypt \\
4 & V 92/17 $\left(\mathrm{P}_{4}\right)$ & Not available & Yemen \\
5 & V99/17 $\left(\mathrm{P}_{5}\right)$ & Not available & Yemen \\
6 & Sakha $8\left(\mathrm{P}_{6}\right)$ & G. 155/7C//Inia/3/Nielain & Egypt \\
7 & Sahel 1 $\left(\mathrm{P}_{7}\right)$ & CAZO/KAUZ//KAUZ & Egypt \\
\hline
\end{tabular}

\section{RESULTS AND DISCUSSION}

Analysis of variance:

Results of variance analysis of for the traits studied under water stress conditions are presented in Table (2). Results indicated that mean squares due to genotypes were highly significant for all the studied traits. However, mean squares due to parents were highly significant for all traits, except for no. of spikes/plant and no. of grains/spike which were significant only $(p<0.05)$. On the other hand, mean squares due to crosses were highly significant for all traits, except for no. of spikes/plant and grain yield/plant, which were significant only $(p<0.05)$. However, mean squares due to parents vs. crosses ( $\mathrm{P}$ vs. C) were highly significant for all traits, except for no. of grains/spike and grain yield/plant, which were significant only $(p<0.05)$, indicated significant hetrosis.

Table (2): Partioning genotypes degrees of freedom and mean squares for studied traits under water stress.

\begin{tabular}{|l|r|c|c|c|c|c|}
\hline \multicolumn{1}{|c|}{ S.V. } & df & $\begin{array}{c}\text { Heading } \\
\text { date }\end{array}$ & $\begin{array}{c}\text { Plant } \\
\text { height }\end{array}$ & $\begin{array}{c}\text { No. of } \\
\text { spikes/ } \\
\text { plant }\end{array}$ & $\begin{array}{c}\text { No. } \\
\text { grains } \\
\text { /spike }\end{array}$ & $\begin{array}{c}\text { Grain } \\
\text { yield/plant }\end{array}$ \\
\hline Genotypes (G) & 27 & $72.14^{* *}$ & $79.01^{* *}$ & $14.28^{* *}$ & $90.82 * *$ & $55.20 * *$ \\
Parents (P) & 6 & $177.73^{* *}$ & $94.02^{* *}$ & $13.40^{*}$ & $21.99^{*}$ & $86.75^{* *}$ \\
Crosses (C) & 20 & $39.52^{* *}$ & $69.42^{* *}$ & $11.29^{*}$ & $113.51^{* *}$ & $43.19^{*}$ \\
P vs C & 1 & $91.02^{* *}$ & $180.88^{* *}$ & $79.46^{* *}$ & $50.34^{*}$ & $105.85^{*}$ \\
GCA & 6 & $50.94^{* *}$ & $98.04^{* *}$ & $5.48^{*}$ & $32.37^{* *}$ & $47.90^{*}$ \\
SCA & 21 & $16.36^{* *}$ & $5.85^{* *}$ & $4.55^{*}$ & $22.92 *$ & $35.75^{*}$ \\
GSA/SCA & & 3.11 & 16.76 & 1.20 & 1.41 & 1.34 \\
\hline
\end{tabular}

*.** significant at $5 \%$ and $1 \%$ levels of probability, respectively. 
Mean performance:

Mean performance of the studied traits of the 7 wheat parental genotypes and their 21 diallel $F_{1}$ crosses under water stress are presented in Table (3). Among the parental genotypes V92/17, Line 39 and V99/17 were the earliest parents $(80.03,80.08$ and 80.16 days, respectively). Moreover, crosses V 99/17 x Sakha 8, Line 54 x V 99/17 and Line 39 x Sakha 8 were the earlier in days to heading (75.99, 76.15 and 76.57 days, respectively). These results suggest that these three crosses could be useful as source of genes for earliness under water stress conditions. Similar finding were obtained by Abd ElRahman (2004).

For plant height, all genotypes differed significantly from $65.00 \mathrm{~cm}$. for V 99/17 x Sakha 8 to $98.50 \mathrm{~cm}$. for V 92/17 x Sakha 8. Meanwhile, parents differed significantly from $82.33 \mathrm{~cm}$. for Line 54 to $97.33 \mathrm{~cm}$. for V 92/17. However, two crosses were significantly shorter than the shortest parent i.e.g. V 99/17 x Sakha 8 (65.00 cm.) and Line 39 x V 92/17 (70.12 cm.). These results suggest that these two crosses could be useful as source of genes for shorter plant height. However, most of the crosses were moderate in plant height, suggesting their usefulness as a source of genes for moderate plant height under water stress conditions. Similar finding were obtained by Moursi (2003).

The crosses exhibited a wide range of variation in no. of spikes/plant ranging from 11.55 for Line 39 x Sahel 1 to 20.82 for Line 39 x Sahel 1. For parents, the range was 15.5 (Sahel 1) to 21.25 (V 92/17) for no. of spikes/plant. Results revealed that no crosses exceeded no. of spikes/plant than the highest parent. However, five crosses (V 92/17 x Sahel 1 and Line 39 x V 92/17) were similar with the highest parent for no. of spikes/plant under water stress conditions.

Results in Table (3) show that no. of grains/spike ranged from 57 (Line $39 \times$ Sahel 1) to 77 (Line $54 \mathrm{x}$ New valley), while among parents the range was from 61.80 (V99/17) to 69.60 (Line 39). However, two crosses (New valley x V 92/17 and Line 54 x New valley) were significantly higher than the highest parent for no. of grains/plant under water stress conditions. Similar results were obtained by Hefnawy and Wahba (2003) and Moursi (2003).

Significant differences among crosses were found for grain yield/plant. It ranged from $38.61 \mathrm{gm}$ for Line $39 \mathrm{x}$ V 92/17 to 58.739 for Line 39 x V92/17 (Table 3). For parents, the range was from 34.41 for Line 54 to $49.57 \mathrm{gm}$ for Sakha 8. Moreover; only one cross (Line 39 x V 92/17) surpassed the highest parent significantly in grain yield/plant, indicating that this crosses could be useful as source of genes for high grain yield/plant under water stress conditions. Similar results were obtained by Gupta et al. (2001) and Abd ElRahman (2004).

\section{Combining ability:}

Analysis of variance of general (GCA) and specific (SCA) combining ability are presented in Table (2). Results showed highly significant estimates of GCA for the studied traits, except for no. of spikes/plant and grain yield/plant which were significant only $(P<0.05)$. Also, significant estimates of SCA were found for the studied traits, except for days to heading and plant height which were highly significant only $(P<0.01)$. These results indicated that both additive and non-additive gene effects played important roles in the inheritance of all the studied traits particularly for earliness and plant height.

Fayoum J. Agric. Res. \& Dev., Vol.23, No.1, January, 2009 
PERFORMANCE OF BREAD WHEAT DIALLEL AMONG.

Table (3): Mean performance of studied traits in wheat parents and $F_{1}$ crosses evaluated under water stress conditions in 2007/2008.

\begin{tabular}{|c|c|c|c|c|c|}
\hline Genotypes & $\begin{array}{c}\text { Heading } \\
\text { date }\end{array}$ & $\begin{array}{c}\text { Plant } \\
\text { Height }(\mathbf{c m})\end{array}$ & $\begin{array}{c}\text { No. of } \\
\text { spikes/plant }\end{array}$ & $\begin{array}{l}\text { No. grains } \\
\text { /spike }\end{array}$ & $\begin{array}{c}\text { Grain } \\
\text { yield/plant (g) }\end{array}$ \\
\hline Line 39 (P1) & 80.08 & 89.50 & 19.58 & 69.60 & 47.43 \\
\hline Line 54 (P2) & 85.20 & 82.33 & 18.72 & 64.20 & 34.41 \\
\hline New valley (P3) & 84.94 & 83.67 & 16.98 & 62.60 & 48.92 \\
\hline V 92/17 (P4) & 80.03 & 97.33 & 21.25 & 62.40 & 42.40 \\
\hline V 99/17 (P5) & 80.16 & 91.83 & 16.65 & 61.80 & 42.13 \\
\hline Sakha 8 (P6) & 82.54 & 86.00 & 19.68 & 65.20 & 49.57 \\
\hline Sahel 1 (P7) & 86.25 & 82.50 & 15.15 & 69.00 & 47.33 \\
\hline $\mathrm{P} 1 \mathrm{xP2}$ & 80.25 & 89.50 & 14.72 & 63.00 & 43.00 \\
\hline P1xP3 & 84.08 & 89.50 & 14.35 & 70.90 & 48.43 \\
\hline P1xP4 & 83.41 & 70.12 & 20.82 & 59.40 & 58.73 \\
\hline P1xP5 & 83.24 & 80.83 & 17.15 & 58.80 & 42.13 \\
\hline P1xP6 & 76.57 & 91.00 & 14.88 & 60.00 & 43.15 \\
\hline P1xP7 & 82.24 & 89.50 & 11.55 & 57.00 & 48.41 \\
\hline P2xP3 & 79.86 & 84.67 & 15.48 & 77.10 & 45.26 \\
\hline P2xP4 & 79.49 & 82.40 & 15.68 & 59.70 & 38.61 \\
\hline P2xP5 & 76.15 & 83.83 & 15.35 & 60.00 & 40.26 \\
\hline P2xP6 & 80.78 & 86.50 & 16.28 & 64.90 & 40.15 \\
\hline P2xP7 & 88.78 & 83.33 & 16.35 & 70.10 & 42.26 \\
\hline P3xP4 & 83.44 & 93.83 & 12.82 & 77.00 & 42.40 \\
\hline P3xP5 & 83.44 & 91.83 & 14.75 & 63.80 & 42.13 \\
\hline P3xP6 & 81.44 & 86.83 & 17.15 & 62.60 & 51.57 \\
\hline P3xP7 & 83.44 & 85.00 & 16.32 & 59.60 & 48.89 \\
\hline P4xP5 & 81.78 & 97.50 & 17.28 & 61.80 & 42.13 \\
\hline P4xP6 & 81.11 & 98.50 & 17.25 & 66.00 & 43.69 \\
\hline P4xP7 & 85.11 & 95.67 & 17.55 & 68.10 & 41.93 \\
\hline P5xP6 & 75.99 & 65.00 & 17.35 & 59.00 & 42.13 \\
\hline P5xP7 & 82.21 & 91.17 & 15.82 & 69.40 & 46.61 \\
\hline P6xP7 & 84.25 & 84.67 & 17.95 & 73.80 & 47.33 \\
\hline L.S.D. $5 \%$ & 2.24 & 4.80 & 3.88 & 5.66 & 8.16 \\
\hline
\end{tabular}

In general, for all studied traits, the magnitude of mean squares due to GCA was higher than that due to SCA. The ratio of GCA/SCA exceeded the unity, suggesting that additive was much larger and more important than nonadditive gene effects in the inheritance of these traits. This was more pronounced in plant height followed by days to heading than the other traits. The higher importance of GCA over SCA variance for studied traits was also reported by Afiah and Darwish (2002) for no. of grains/spike under rain-fed stress, Hassani et al. (2005) for days to heading, plant height no. of grains/plant under well water, Darwish (2003) for no. of grains/plant under stress

Fayoum J. Agric. Res. \& Dev., Vol.23, No.1, January, 2009 
conditions (one irrigation) and Al-Naggar et al. (2007) for days to heading and grain yield/plant under irrigated and water stress conditions.

Estimates of GCA effects for the studied traits are presented in Table (4). Results showed that the parents V92/17, V 99/17 and Sakha 8 had significant and negative

Table (4): Estimates of general combining ability effects of wheat parents for several traits under water stress conditions.

\begin{tabular}{|l|c|c|c|c|c|}
\hline Parents & $\begin{array}{c}\text { Heading } \\
\text { date }\end{array}$ & $\begin{array}{c}\text { Plant } \\
\text { height }\end{array}$ & $\begin{array}{c}\text { No. of } \\
\text { spikes/plant }\end{array}$ & $\begin{array}{c}\text { No. grains } \\
\text { /spike }\end{array}$ & $\begin{array}{c}\text { Grain } \\
\text { yield/plant }\end{array}$ \\
\hline Line 39 (P1) & $1.21 *$ & 0.30 & $1.33 *$ & $7.03 *$ & $2.50 *$ \\
Line 54 (P2) & $5.05 *$ & -0.46 & $0.77 *$ & -1.69 & $-3.0 *$ \\
New valley (P3) & $1.70 *$ & $0.98 *$ & $0.47 *$ & $-6.17 *$ & -0.55 \\
V 92/17 (P4) & $-0.72 *$ & $-0.76 *$ & $0.50 *$ & $-2.06 *$ & 1.33 \\
V 99/17 (P5) & $-3.94 *$ & 0.30 & $-1.23 *$ & $1.87 *$ & -0.04 \\
Sakha 8 (P6) & $-4.76 *$ & $-2.72 *$ & -0.25 & 0.76 & 1.73 \\
Sahel 1 (P7) & $1.47 *$ & $0.85 *$ & $-1.58 *$ & 0.27 & -1.38 \\
\hline SE 0.05 (gi) & 0.24 & 0.27 & 0.18 & 0.90 & 1.25 \\
SE 0.05 (gi-gj) & 0.99 & 4.48 & 2.93 & 14.69 & 20.36 \\
\hline
\end{tabular}

*.** significant at $5 \%$ and $1 \%$ levels of probability, respectively.

GCA effects (desirable) for days to heading under water stress conditions. These parents could be considered the best general combiners for the improvement of earliness traits in breeding programs.

For plant height two parents (Sakha 8 and V92/17) had significant and negative GCA effects. These parents could be considered the best general combiners for the improvement of shortness in breeding programs.

For no. of spikes/plant the best general combiners were Line 39 followed by Line 54, V92/17 and then New valley. On the other hand, for no. of grains/plant the best general combiners were Line 39 followed by Line V99/17.

For grain yield/plant the best general combiner was Line 39. Evaluation of significance GCA effects for a specific trait guide the breeder to select parents for improving this trait. Similar results were estimated by Sultan et al. (2006) for no. of spikes/plant, no. of grains/spike and grain yield/plan under water stress conditions.

Specific combining ability (SCA) effects of the $F_{1}$ crosses for the studied traits are shown in Table (5). The results of days to heading (earliness) revealed that the $\mathrm{F} 1$ crosses showing positive SCA effects (unfavorable) outnumbered those showing negative SCA effects (favorable). The best SCA effects for days to heading was obtained from crosses Line 39 x Sahel 1, Line 39 x line 54, Line 54 x New valley, Line 54 x V 92/17, New Valley x Sahel 1, Line 54 x V 99/17, V 99/17 x Sakha 8 and New Valley x V 92/17. Moreover, such good SCA crosses might came from two parents possessing good GCA or from one with good GCA and other with poor GCA effects for earliness trait.

Fayoum J. Agric. Res. \& Dev., Vol.23, No.1, January, 2009 
PERFORMANCE OF BREAD WHEAT DIALLEL AMONG.

Table (5): Estimates of specific combining ability effects of $F_{1}$ crosses for studied Traits.

\begin{tabular}{|l|c|c|c|c|c|}
\hline Crosses & $\begin{array}{c}\text { Heading } \\
\text { date }\end{array}$ & $\begin{array}{c}\text { Plant } \\
\text { height }\end{array}$ & $\begin{array}{c}\text { No. of } \\
\text { spikes/plant }\end{array}$ & $\begin{array}{c}\text { No. grains } \\
\text { /spike }\end{array}$ & $\begin{array}{c}\text { Grain } \\
\text { yield/plant }\end{array}$ \\
\hline P1xP2 & $-5.67 *$ & 0.11 & -1.13 & -1.12 & 2.26 \\
P1xP3 & $0.62 *$ & 0.17 & -0.78 & $5.34 *$ & 0.68 \\
P1xP4 & $1.20 *$ & -0.02 & $3.57 *$ & -4.00 & $2.84 *$ \\
P1xP5 & $4.68 *$ & -1.93 & 1.33 & -2.34 & -0.97 \\
P1xP6 & $4.75 *$ & 0.39 & -1.96 & -3.39 & $-2.79 *$ \\
P1xP7 & $-7.99 *$ & $-4.19 *$ & $-3.70 *$ & $-8.54 *$ & 2.04 \\
P2xP3 & $-4.24 *$ & -1.46 & 0.50 & $9.88 *$ & $-3.87 *$ \\
P2xP4 & $-3.37 *$ & 0.69 & -1.42 & -5.36 & 0.70 \\
P2xP5 & $-2.37 *$ & 1.28 & -0.32 & -2.79 & 1.49 \\
P2xP6 & $1.65 *$ & -0.91 & -0.41 & -0.15 & -1.45 \\
P2xP7 & $3.91 *$ & -2.28 & 1.25 & 2.91 & 0.22 \\
P3xP4 & $-0.95 *$ & -0.93 & $-3.57 *$ & $10.50 *$ & -1.53 \\
P3xP5 & $3.37 *$ & 1.33 & -0.20 & -0.44 & -2.66 \\
P3xP6 & $0.77 *$ & -0.52 & 1.17 & -3.89 & 1.95 \\
P3xP7 & $-2.97 *$ & -0.56 & 1.94 & $-9.04 *$ & -0.17 \\
P4xP5 & $2.95 *$ & -1.69 & 0.21 & -0.28 & 1.85 \\
P4xP6 & $1.68 *$ & 2.46 & -0.85 & 1.66 & 0.58 \\
P4xP7 & -0.06 & 1.43 & 1.05 & 1.62 & -1.62 \\
P5xP6 & $-2.11 *$ & -0.78 & 0.69 & -3.07 & -1.84 \\
P5xP7 & $1.36 *$ & 1.19 & 0.75 & 5.18 & 2.20 \\
P6xP7 & $2.80 *$ & -2.17 & 1.86 & $7.33 *$ & 0.09 \\
\hline SE 0.05 (sij) & 0.14 & 1.47 & 1.52 & 2.75 & 1.45 \\
SE 0.05 (sij-sik) & 0.98 & 2.12 & 2.93 & 3.83 & 2.95 \\
\hline
\end{tabular}

*.** significant at $5 \%$ and $1 \%$ levels of probability, respectively.

$\mathrm{P}_{1}=$ Line 39, $\mathrm{P}_{2}=$ Line 54, $\mathrm{P}_{3}=$ New valley, $\mathrm{P}_{4}=\mathrm{V}$ 92/17, $\mathrm{P}_{5}=\mathrm{V}$ 99/17, $\mathrm{P}_{6}=$ Sakha $8, \mathrm{P}_{7}=$ Sahel 1

The lowest significant and negative SCA effects for plant height (shortness) was obtained from cross Line 39 x Sahel 1. Moreover, for no. of spikes/plant there was also one cross (Line 39 x V 92/17) exhibited positive SCA effects. These results might come from two parents possessing good GCA effects for no. of spikes/plant. On the other hand, four crosses (New valley x V 92/17, Line 54 x New valley, Sakh 8 x Sahel 1 and Line 39 x New valley) showed positive SCA effects for no. of grains/spike. One cross (Line 39 x V 92/17) showed the best SCA effects for grain yield/plant.

\section{REFERENCES}

Abd El-Rahman, E. Magda (2004). Genetical analysis and evaluation of drought tolerance trait under different conditions in wheat (Triticum aestivum L.). Ph. D. Thesis, Tanta Univ., Egypt.

Afiah, S.A.N. and I.H.I. Darwish (2002). Combining ability analysis and heterosis in relation to salinity and drought stress for yield and its attributes of bread wheat. J. Agric. Sci. Mansoura Univ., 27(6):833-849

Agenbag, G.A. and O.T.De Villiers (1995). Physiological response of spring wheat cultivars to post-anthesis water stress intensity. South African J. of Plant and Soil, 12(1): 27-31.

Fayoum J. Agric. Res. \& Dev., Vol.23, No.1, January, 2009 
Al-Naggar, A.M., M.A. Moustafa, M.M. Atta and M.T. Shehab-Eldeen (2007). Gene action of earliness and grain filling in bread wheat under two irrigation regimes. Egypt. J. Plant Breed., 11(3):1-22.

Arshad, M. and M.A. Chowdhry (2003). Genetic behavior of wheat under irrigated and drought stress environment source. Aust. J. Plant Sci., 2:58-64.

Ashraf, M. Y. (1988). Yield and yield components response of wheat genotypes grown under different soil water deficit conditions. Acta Agron. Hung., 46:45-51.

Ashraf, M.Y. and S.S. Naqvi (1995). Studies on wheat uptake, germination and seedling growth of wheat genotypes under PEG-6000 induced water stress. Pak. J. Sci. Ind. Res., 38:130-133.

Avey, D.P., H.W. Ohm, F.L. Patterson and W.E. Nyquist (1982). Advanced generation analysis of days to heading in three winter wheat crosses. Crop Sci., 22:912-915.

Bhatt, G.M. (1972). Inheritance of heading date, plant height and kernel weight in two spring wheat crosses. Crop Sci., 12:95-98.

Clarke, J.M., R.M. De Pauw and T.M. Townley-Smith. (1992). Evaluation of methods for quantification of drought tolerance in wheat. Crop Sci. $32,728-732$.

Clarke, J.M., T.F.S. Townley, T.N.C. Mc and D.G. Green (1984). Growth analysis of spring wheat cultivars of varying drought resistance. Crop Sci., 24:537-541.

Cooper, M.R.E., Stucker, I.H. Delacy and B.D. Harch (1997). Wheat breeding nurseries, target environments and indirect selection for grain yield. Crop Sci., 34:1168-1176.

Crumpacker, D.W. and R.W. Allard (1962). A diallel cross analysis of heading date in wheat. Hilgardia, 32:275-318.

Darwish, I.H.I. (2003). Diallel cross analysis of wheat (Triticum aestivum L.) under stress and normal irrigation treatments. Egypt J. Plant Breed., 7:253-269.

El-Banna, M.N.M., A.A. Nassar, M.A. Moustafa and S.H. Abd-Allah (2002). Evaluation of some wheat genotypes under drought conditions in Nubaria region. J. Adv. Agric. Res., 7:349-366.

FAO (1988). World Agriculture Toward 2000: an FAO Study. Belhaven Press, London.

Fischer, R.A. and R. Maurer (1978). Drought resistance in spring wheat cultivars. I. Grain yield responses. Aust. J. Agic. Res., 29:897-912.

Freed, R., S.P. Einensmith, S. Gutez, D. Reicosky, V.W. Smail and P. Wolberg (1989). User's Guide to MSTAT-C Analysis of Agronomic Research Experiments. Michigan State University, East Lansing, USA.

Griffing, B. (1956). Concept of general and specific combining ability in relation to diallel crossing system. Aust. J. Biol. Sci., 9:463-493.

Gupta, N.K., S. Gupta and A. Kumar (2001). Effect of water stress on physiological attributes and their relationships with growth and yield of wheat cultivars at different stages. J. Agron. and Crop Sci., 186(1): 5562.

Hassani, M., G. Saeidi and A. Rezai (2005). Estimation of genetic parameters and combining ability for yield and yield components in bread wheat. J. of Sci. Techn. Of Agric. and Natural Res., 9(1): 157-171.

Fayoum J. Agric. Res. \& Dev., Vol.23, No.1, January, 2009 
Hefnawy F.A. and M.F. Wahba (2003). Effect of drought stress during growth stages on durum wheat (Triticum turgidum var durum). Egypt J. Appl. Sci., 18(2): 120-127.

Iqbal, M., K. Ahmed, I. Ahmed, M. Sadiq and M.Y. Ashraf (1999). Yield and yield components of durum wheat as influenced by water stress at various growth stages. Paki. J. Biol. Sci., 2:11-14.

Kashif, M. and I. Khaliq (2003). Mechanism of genetic control of some quantitative traits in bread wheat. Paki. J. Biol. Sci., 6(18):1586-1590.

Kheiralla, K.A., M.M. El-Defrawy and Tahany H.I. Sherif (1993). Genetic analysis of grain yield, biomass and harvest index in wheat under drought stress and normal moisture conditions. Assuit J. of Agric. Sci., 24(3): 164-182.

Menshawy, A.M.M. (2000). Genetic studies on spring wheat. Ph. D. Thesis, Zagazig Univ., Egypt.

Menshawy, A.M.M. (2005). Genetic analysis for earliness components in some wheat genotypes of different photothermal response. Egypt J. Plant Breed. 9(1): 31-47.

Moursi, A. M. (2003). Performance of grain yield for some wheat genotypes under stress by chemical desiccation. Ph. D. Thesis, Zagazig Univ., Egypt.

Nasir Ud-Din, B.F. and A.C. Carver (1992). Genetic analysis and selection for wheat yield in drought-stressed and irrigated environments, Euphytica (62):89-96.

Neter, J., M. Khutner, C. Nachtsheim and W. Wasserman (1996). Applied Linear Statistical Models. $4^{\text {th }}$ Ed. Irwin Series. Time Mirror. Education Group, 111-121.

Ozturk, A. and F. Aydin (2004). A better understanding of wheat stress influences is important for plant breeders developing cultivars. J. Agron. and Crop Sci., 190:93-99.

Poehlman, J.W. (1987). Breeding Field Crops. $3^{\text {rd }}$ Ed. AVI Publishing Company Inc. Wastport, Comm, U.S.A. 724 pp.

Rascio, A., C. Platani, N. Difonza and G. Wittemer (1992). Bound water in durum wheat under drought stress. Plant Physiol., 98:908-912.

Rebetzke, G.I., A.G. Condon, R.A. Richards and G.D. Farquhar (2002). Selection for reduced carbon-isotope discrimination increases aerial biomass and grain yield of rain-fed bread wheat. Crop Sci., 42: 739745.

Richards, R.A., A.G. Condon and G.J. Rebetzke (2001). Traits to improve yield in dry environments. In: M.P. Reynolds, J.I. Ortiz-Monasterio and A. McNab (Eds.), Application of Physiology In Wheat Breeding, pp. 88-100. CIMMYT, Mexico.

Richards, R.A., G.J. Rebetzke, A.G. Condon and A. Van Herwaarden (2002). Breeding for greater water stress use efficiency in wheat. Crop Sci., 42:111-121.

Sinha, S.K., P.K. Aggarwal, G.S. Chaturvedi, A.K. Singh and K. Kailasnathan (1986). Performance of wheat and triticale cultivars in a variable soil water environment. I. Grain yield stability. Field Crop Res., 13:289-299.

Fayoum J. Agric. Res. \& Dev., Vol.23, No.1, January, 2009 
Mohamed A. Abd El-Shafi, et al.

Sultan, M.S., M.H. El-Hindi, A.E. Sharief, A.H. Abd El-Latif and M.N. A. El-Hawary (2006). Genetic analysis of some bread wheat crosses under normal and water stress conditions. Egypt. J. Plant Breed., 10(2): 249265.

أداء الهجين الدائري لسبعة اصناف من قمح الخبز تحت ظروف الاجهاد المائى

محمد عبد المعبود عبد الثافي، أشرف عبد الأعلي عبد المحسن وسوسن عبد البديع الصادي

قسم المحاصيل - كلية الزراعة ـ جامعة القاهرة

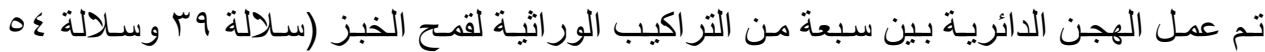

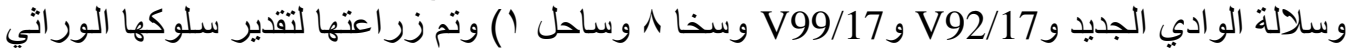

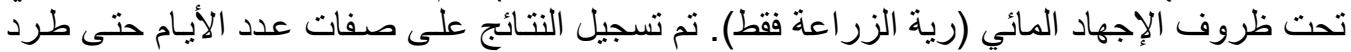

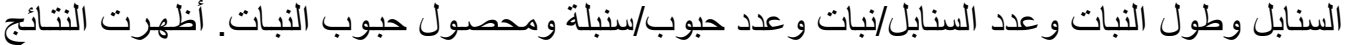

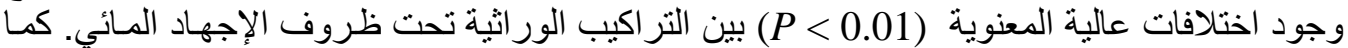

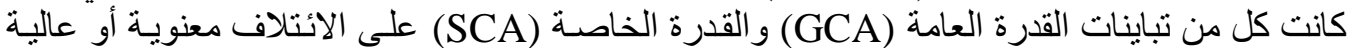

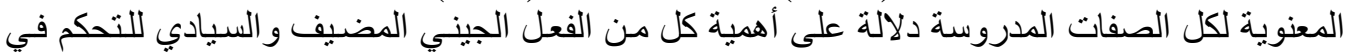

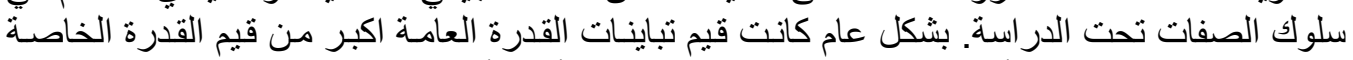

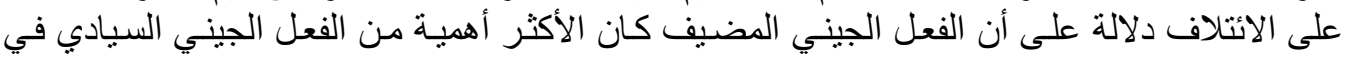
توريث هذه الصفات.

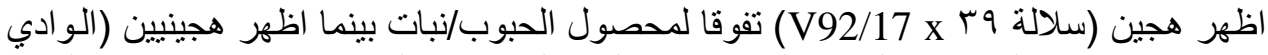

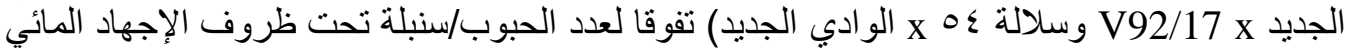
ويمكن استخدامهم بغرض التحسين وخصوصـا أن أبـاء هذه الهجن أظهرت قدرة التهن على التآلف يمكن استخدامها لتحسين هذه الصفات. 